\title{
PEMENUHAN KEBUTUHAN DASAR ANAK OLEH ORANG TUA PASCA PERCERAIAN
}

\author{
Isa Vila Rizki Ullabanati \\ Sarjana (S1) FISIP Universitas Jember \\ Program Studi Ilmu Kesejahteraan Sosial \\ isavilarizki43@gmail.com \\ Mahfudz Sidiq \\ Dosen FISIP Universitas Jember, \\ Program Studi Ilmu Kesejahteraan Sosial \\ Fudzdiq2@gmail.Com
}

\begin{abstract}
Jember is a district with a high divorce rate in the East Java province. Divorcing leaves behind a victim which is the child of a divorced couple. Children who are victims of broken home usually have negative behavior both for themselves and the surrounding environment due to family conditions that are broke apart. In addition, the needs of broken bome child unlike when the family is still intact. But the children's victim of the divorced parents in Tegalsari Village did not show deviant behavior like most children who were victims of broken home. The purpose of this study is to describe how to fulfill the basic needs of children by parents after divorce. The approach of this research is qualitative and uses descriptive type of research. Determination of informants in this study using a purposive technique. The technique of collecting data uses observation, interviews, and documentation. Data analysis used data reduction, data presentation, and conclusion or verification. The data validity technique used is in the form of source triangulation. The results showed that both divorced parents still met their children's needs even though they were not in one house. Needs fulfilled by parents are educational needs, health needs and needs of achievement. The way fathers and mothers fulfill their children's needs is somewhat different. Mothers in meeting their children's needs are more responsive, organized and resilient starting from simple things to serious problems. While the father in fulfilling his children's needs is less sensitive to the needs of his child. It means that the father in meeting the needs of his children seems serious
\end{abstract}




\section{Isa Vila Rizki Ullabanati, Mahfudz Sidiq}

when the problem is considered very important, for example a child who is seriously ill must be taken to the hospital and others.

\section{Keywords: Divorce, Basic Need, Child}

\section{Abstrak}

Jember merupakan salah satu kabupaten dengan tingkat perceraian yang tinggi di Provinsi Jawa Timur. Perceraian meninggalkan korban yang merupakan anak dari pasangan yang bercerai. Anak-anak yang menjadi korban broken home biasanya memiliki perilaku negatif baik terhadap diri sendiri maupun lingkungan sekitarnya akibat kondisi keluarga yang berantakan. Selain itu, kebutuhan anak broken home tidak seperti saat keluarga masih utuh. Namun anak-anak korban dari orang tua yang bercerai di Desa Tegalsari tidak menunjukkan perilaku menyimpang seperti kebanyakan anak yang menjadi korban broken home. Tujuan penelitian ini adalah untuk mendeskripsikan bagaimana pemenuhan kebutuhan dasar anak oleh orang tua pasca perceraian. Pendekatan penelitian ini adalah kualitatif dan menggunakan jenis penelitian deskriptif. Penentuan informan dalam penelitian ini menggunakan teknik purposive. Teknik pengumpulan data menggunakan observasi, wawancara, dan dokumentasi. Analisis data menggunakan reduksi data, penyajian data, dan penarikan kesimpulan atau verifikasi. Teknik keabsahan data yang digunakan berupa triangulasi sumber. Hasil penelitian menunjukkan bahwa kedua orang tua yang bercerai tetap dapat memenuhi kebutuhan anaknya meskipun tidak berada dalam satu rumah. Kebutuhan yang dipenuhi oleh orang tua adalah kebutuhan pendidikan, kebutuhan kesehatan dan kebutuhan berprestasi. Cara ayah dan ibu memenuhi kebutuhan anak mereka agak berbeda. Ibu dalam memenuhi kebutuhan anaknya lebih tanggap, teratur dan ulet mulai dari hal yang sederhana hingga masalah yang serius. Sedangkan ayah dalam memenuhi kebutuhan anaknya kurang peka terhadap kebutuhan anaknya. Artinya bapak dalam memenuhi kebutuhan anaknya nampak serius padahal masalah dianggap sangat penting, misalnya anak yang sakit parah harus dibawa ke rumah sakit dan lain-lain.

\section{Kata Kunci : Perceraian, Kebutuhan Dasar, Anak}




\section{Pendahuluan}

Keluarga dianalogikan seperti satu kesatuan organ tubuh manusia (kepala, tangan, jantung, dan lainlain). Jika salah satu anggota tubuh mengalami gangguan atau ketidakberfungsian, maka akan mempengaruhi dan mengganggu keberfungsian anggota tubuh yang lainnya. Begitu pula dengan keluarga, individu-individu di dalam keluarga saling berkaitan, mempengaruhi dan bergantung satu sama lain. jika salah satu anggota keluarga mengalami ketidakberfungsian perannya di dalam keluarga maka seluruh sistem di dalam keluarga tersebut akan terganggu pula.

Namun tidak dapat dipungkiri bahwa konflik akan selalu terjadi di dalam keluarga. Hal ini karena masing-masing anggota keluarga memiliki sikap dan pemikiran yang berbeda. Seringkali konflik bisa teratasi dengan baik namun ada juga yang sulit mengatasinya. Konflik yang sulit diselesaikan dalam keluarga dapat menyebabkan keretakan rumah tangga yang berujung perceraian. Perceraian dipilih karena dianggap sebagai jalan terakhir dalam menyelesaikan permasalahan pasangan suami-istri. Jika perceraian terjadi, maka struktur dalam keluarga tersebut akan mengalami perubahan. Begitu juga dengan keberfungsian individu di dalam keluarga. Selain itu perceraian akan mempengaruhi tercapainya pemenuhan kebutuhan materi maupun non materi (psikologis) setiap anggota keluarga tersebut terutama anak.

Banyaknya dampak negatif yang terjadi akibat perceraian, pada kenyataannya tidak mengurangi rasio tingkat perceraian di Indonesia. Berikut data perkawinan dan per- 
Isa Vila Rizki Ullabanati, Mahfudz Sidiq

ceraian di Indonesia 2012 sampai 2015.

Tabel 1.

Jumlah Perkawinan dan Perceraian di Indonesia

\begin{tabular}{|c|c|c|}
\hline Tahun & Perkawinan & Perceraian \\
\hline 2012 & 2.289 .648 kejadian & 346.480 kejadian \\
\hline 2013 & 2.210 .046 kejadian & 324.247 kejadian \\
\hline 2014 & 2.110 .776 kejadian & 344.237 kejadian \\
\hline 2015 & 1.95 .394 kejadian & 347.256 kejadian \\
\hline
\end{tabular}

Angka perceraian di atas merupakan akumulasi dari setiap provinsi di Indonesia. Dari data di atas diketahui angka perceraian di Indonesia semakin meningkat di setiap tahunnya. Hal ini menunjukkan perceraian merupakan masalah yang serius bagi pemerintah. Pada awal tahun 2016, Jawa Timur merupakan salah satu penyumbang angka perceraian terbesar. Menteri Sosial, Parawansa menyatakan, dalam beberapa tahun terakhir ini angka perceraian di Indonesia melonjak drastis dan Jawa Timur merupakan penyumbang terbesar dalam kasus perceraian di tanah air hingga mencapai 47 persen atau hampir separuh kasus perceraian di Indonesia ada di Jawa Timur ${ }^{1}$. Kabupaten Jember merupakan salah satu penyumbang angka perceraian terbesar. Tahun 2015 angka perceraian di Kabupaten Jember menembus 6108 kasus dan pada tahun 2016 angka perceraian mencapai 5793 kasus $^{2}$. Diketahui pada bulan Agustus 2017 angka perceraian mencapai 1667 kasus dan pada bulan September 2017 angka perceraian meningkat mencapai 1804 kasus $^{3}$.

Kasus perceraian hampir merata di 31 Kecamatan, Kecamatan Ambulu salah satu kecamatan penyumbang angka perceraian terbesar di Kabupaten Jember ${ }^{4}$. Desa Tegalsari merupakan salah satu desa dengan angka perceraian cukup tinggi dengan berbagai macam faktor. Faktor perceraian

\footnotetext{
1 https://regional.kompas.com/ (8 Oktober 2017).

2 http://www.kbknews.id/ $\quad(8$ Oktober 2017).

${ }^{3}$ http://olahkabar.com/ (8 Oktober 2017).

4 http://www.antarajatim.com/ Oktober 2017).
} 
terbanyak disebabkan kekerasan dalam rumah tangga. Selain itu masyarakatnya sangat terbuka terhadap perubahan sosial sehingga berakibat pada tingginya angka perceraian.

Anak yang menjadi korban perceraian dari kedua orang tuanya akan berpotensi melakukan perilaku menyimpang. Menurut Jensen (dalam Sarwono) $)^{5}$ bahwa perceraian orang tua mempunyai dampak negatif terhadap anak dan dapat merugikan diri sendiri serta orang lain, seperti merokok, memakai narkoba, meminum-minuman keras, seks bebas, dan mengingkari status sebagai pelajar dengan cara membolos. Namun yang terjadi di Desa Tegalsari, anak yang mengalami korban perceraian dari kedua orang tuanya menunjukkan perilaku

\footnotetext{
${ }^{5}$ Sarwono, S.W. Psikologi Sosial Individu dan Teori-Teori Psikologi Sosial Jakarta: Balai Pustaka, 2002), .205.
}

yang tidak menyimpang seperti pada umumnya anak broken home.

Pada kondisi lapangan terdapat karang taruna yang di dalamnya terdapat anak-anak yang aktif dalam melakukan berbagai macam kegiatan, termasuk anak dari korban perceraian. Kegiatan yang dilakukan oleh anak-anak tersebut diantaranya adalah membersihkan lingkungan desa, mengikuti pengajian, kegiatan olahraga dan berbagai macam kegiatan yang diselenggarakan oleh desa. Tidak hanya itu, sebagian anak-anak dari korban perceraian berstatus siswa SMA favorit dan sisanya siswa SMP di Kecamatan Ambulu. Selain itu anak yang di asuh oleh ibu dan ayah single parent $t^{6}$ Jumlah sekolah yang ada di Kecamatan Ambulu baik Sekolah Dasar hingga Sekolah Menengah Atas mencapai 104 2017

${ }^{6}$ Observasi awal peneliti, Oktober 


\section{Isa Vila Rizki Ullabanati, Mahfudz Sidiq}

sekolah yang terletak di tiga desa.

Desa Tegalsari memiliki 10 sekolah mulai dari Sekolah Dasar sampai SMA (Kemendikbud, 2018). Dengan demikian tidak ada kesulitan anak-anak untuk dapat mengenyam pendidikan di berbagai jenjang pendidikan. Anak korban perceraian merupakan anak yang cukup berprestasi baik dari akademik maupun non akademik, seperti tabel berikut:

Tabel 2.

Jenjang Penddikan dan Prestasi Anak Korban Perceraian

maupun non akademik. Selain itu kesehatan anak korban perceraian juga cukup baik, di tahun 20162017 dari 118 anak yang merupakan korban perceraian tidak memiliki riwayat penyakit yang kronis. 23 anak tercatat pernah memiliki riwayat penyakit tifus dan sisanya mengalami sakit seperti demam, batuk, flu dan lain-lain. ${ }^{7}$

Berdasarkan fenomena di atas, kondisi kesejahteraan setelah perceraian menjadi hal yang seringkali dipertanyakan terutama pada anak yang menjadi korban

\begin{tabular}{|c|c|c|c|c|}
\hline \multirow{2}{*}{ njang } & \multirow{2}{*}{ Jumlah Siswa } & \multicolumn{2}{|c|}{ Prestasi } & perceraian salah \\
\hline & & Akademik & Non Akademik & Rebutuhan anak untuk menjamin \\
\hline SD & 27 Siswa/i & 3 Siswa/i & 7 Siswa/i & depannya. \\
\hline SMP & 39 Siswa/i & 2 Siswa/i & 5 Sisw & benuhinya kebutuhan tersebu \\
\hline SMA/SMK & 52 Siswa/i & a/i & a/i & a kondisi pasca perce \\
\hline
\end{tabular}

Sumber data: Profil Desa Tegalsari 2016-

2017, dan diolah kembali oleh peneliti

Data di atas menunjukkan bahwa anak korban perceraian juga memiliki pendidikan yang baik dan cukup berprestasi dalam akademik kedua orang tuanya bahkan anak bisa melakukan tindak kejahatan ataupun merusak diri. Dengan demikian tujuan dalam penelitian ini ingin mengetahui, mendeskripsikan,

${ }^{7}$ Arsip Desa Tegalsari Kecamatan Ambulu Kabupaten Jember 2016-2017 
Vol. 12, No. 1, April 2019

p-ISSN:2086 -0749

e-ISSN:2654-4784

dan menganalisis secara mendalam bagaimana pemenuhan kebutuhan anak, baik materi maupun non materi pasca perceraian orang tuanya.

\section{Metode Penelitian}

Penelitian ini menggunakan pendekatan kualitatif, jenisnya studi deskriptif. Lokasi desa Tegalsari Kecamatan Ambulu. Penentuan informan menggunakan teknik purposive, terdiri 10 informan pokok yaitu 5 orang tua dan 5 anak. Informan tambahan 5 kerabat dekat (nenek/kakek) yang tinggal bersama. Teknik pengumpulan data menggunakan observasi nonparticipant, wawancara semiterstruktur, dan dokumentasi. Teknik analisis data melalui tiga tahapan, yaitu reduksi data, display data, dan kesimpulan atau verifikasi data (Miles dan Huberman \{dalam
Sugiyono $^{8}$ \}). Teknik keabsahan data menggunakan triangulasi sumber.

\section{Temuan Penelitian dan}

\section{Pembahasan}

a. Gambaran Umum Lokasi

Penelitian

Tempat penelitian berada di kecamatan Ambulu, Kecamatan tersebut merupakan kecamatan dari 31 kecamatan di Kabupaten Jember, jarak dari Ibu Kota kurang lebih $42 \mathrm{~km}$. Wilayah selatan berbatasan Samudra Hindia, Luas wilayahnya 104,56 $\mathrm{Km}^{2}$ dengan ketinggian rata-rata $35 \mathrm{~m}$ di atas permukaan laut. Kecamatan tersebut meliputi 7 wilayah yaitu: Sumber Rejo, Andong Sari, Sabrang, Tegalsari, Ambulu, Pontang, dan Karanganyar, terdiri dari 27 Dusun,

${ }^{8}$ Sugiyono, Memahami Penelitian Kualitatif (Bandung: Alfabeta, 2015), 91. 


\section{Isa Vila Rizki Ullabanati, Mahfudz Sidiq}

193 Rukun Warga (RW) dan 608 Rukun Tetangga (RT).

Mayoritas penduduknya bekerja sebagai petani, dikarenakan luas wilayah sawahnya melebihi luas pemukiman warga mencapai 191 Ha. Luas wilayanya $366 \mathrm{Ha}$ terdiri dari pemukiman $159.18 \mathrm{Ha}$, sawah $191 \mathrm{Ha}$, perkebunan $2.92 \mathrm{Ha}$, bangunan 9.4 Ha, rekreasi dan olah raga $2.1 \mathrm{Ha}$, dan luas lain-lain 1,4 Ha. Kondisi tanahnya subur dengan curah hujan $1500 \mathrm{~mm} / \mathrm{th}$.

b. Pemenuhan Kebutuhan Anak Pasca Perceraian

\section{Kebutuban Kesehatan}

Kesehatan merupakan kebutuhan dasar bagi seseorang, ketika anak sedang sakit perawatan dari orang tua sangat penting baik dari ayah maupun ibu. Informan selaku orang tua mengungkapkan bahwa antara ayah dan ibu saling membantu dalam mengurusi kesehatan anak meskipun telah bercerai. Mereka tetap saling menjaga komunikasi untuk kepentingan anak-anak mereka. Terlebih ketika anak se- dang sakit. Kebutuhan akan kesehatan fisik dipenuhi oleh orang tua dengan cara agak berbeda. Mulai dari bekerjasama dalam memeriksakan ke dokter, menjenguk ketika sakit, dan memberikan uang berobat. Dari beberapa pernyataan oleh orang tua terlihat bahwa orang tua yang tinggal bersama dengan anak lebih banyak memenuhi kebutuhan kesehatannya daripada orang tua yang meninggalkan rumah atau tidak serumah dengan anakanaknya.

\section{Kebutuban Pendidikan}

Kebutuhan pendidikan sangat penting bagi anak, pendidikan merupakan upaya untuk menjadikan manusia lebih baik dalam melaksanakan tugas-tugas kehidupannya di masa mendatang. Meskipun orang tua telah bercerai, mereka tetap bekerja sama dalam memenuhi kebutuhan pendidikan anaknya. Mereka memenuhi kebutuhan anaknya terlebih lagi orang tua yang tinggal bersama dengan anak. Anak juga merasakan bahwa 
kebutuhan pendidikan terpenuhi dengan baik. Orang tua yang tidak tinggal bersama dengan anak juga berusaha memenuhi kebutuhan anaknya meskipun tidak sebesar yang dilakukan oleh orang tua yang tinggal bersamanya. Setiap orang tua dalam pemenuhan kebutuhan pendidikannya dengan cara yang berbeda-beda.

\section{Kebutuhan Berprestasi}

Dukungan orang tua merupakan salah satu dari tiga sumber dukungan sosial yang diterima oleh yaitu sekolah dan teman sebaya. Oleh karena itu, peran orang tua dalam memenuhi kebutuhan berprestasi pada anak sangat diperlukan. Pada dasarnya kebutuhan berprestasi setiap anak berbedabeda tergantung minat dan potensi di dalam diri anak. Orang tua berperan dalam hal dukungan baik materi maupun non materi. Setelah bercerai kedua orang tua wajib memenuhi kebutuhan anaknya, termasuk kebutuhan berprestasi. Untuk memenuhi kebutuhan berprestasi anak diperlukannya kerja sama antara kedua orang tua. Dukungan tersebut dapat berupa dukungan materi maupun non materi. Dukungan materi dapat diwujudkan dengan memberikan kebutuhan fisik untuk memenuhi kebutuhan capaian prestasinya. Sedangkan dukungan non materi dengan memberi perhatian, nasihat, saran, support, dan motivasi agar dapat mengembangkan potensi dalam diri anak.

c. Upaya Pemenuhan Kebutuhan Dasar Anak oleh Ibu Keluarga yang mengalami perpisahan akibat perceraian atau kematian menyebabkan komposisi keluarga menjadi tidak lengkap, karena keluarga itu hanya memiliki seorang bapak atau seorang ibu bersama anak-anak mereka. Kondi- 


\section{Isa Vila Rizki Ullabanati, Mahfudz Sidiq}

si ini dinamakan posisi single parent, yaitu orang tua tunggal yang memiliki beban pengasuhan terhadap anak-anak mereka. Menurut Karim (dalam Ihromi'), Single parent yang cerai hidup terjadi akibat perceraian, sementara cerai mati biasanya akibat kematian dari pasangan. Informan merupakan orang tua tunggal akibat cerai hidup. Ibu sebagai orang tua tunggal yang tinggal dengan anak berusaha memenuhi kebutuhan anaknya. Dengan status ibu sebagai single parent otomatis mengambil peran ganda yaitu peran ayah dan peran ibu. Kebutuhan anak yang telah terpenuhi oleh ibu yaitu kebutuhan pendidikan, kebutuhan kesehatan, dan kasih sayang. Upaya pemenuhan merupakan suatu bentuk usaha ibu sebagai orang tua tunggal dalam memenuhi kebutuhan anaknya. Berikut ini akan di bahas beberapa kebutuhan anak oleh ibu sebagai single parent:

${ }^{9}$ Ihromi, T.O, Bunga Rampai Sosiologi Keluarga (Jakarta: Yayasan Obor Indonesia, 2004), 156.

\section{Kebutuban Pendidikan}

Sebagai orang tua tunggal, ibu juga memiliki pekerjaan untuk memenuhi kebutuhan hidupnya sehari-hari. Ibu yang single parent diantaranya bekerja sebagai pegawai cafe dan membuka toko klontong. Meskipun Ibu bekerja, tetapi mereka tetap meluangkan waktunya dalam mengurus anak terutama dalam hal pendidikan. Bentuk pemenuhan kebutuhan non materi adalah memberikan motivasi kepada anaknya dalam belajar, jika anak malas belajar ibu memberikan nasihat agar giat belajar. Selain pendidikan formal, ia juga memberikan pendidikan rohani anak-anaknya. Pendidikan rohani yang diberikannya bermacam-macam sesuai dengan agamanya seperti menasihati untuk selalu beribadah, terlebih lagi jika ada di lingkungan agamis. Dengan pendidikan rohani diharapkan setelah dewasa mampu menjalankan ajaran agama sesuai dengan keyakinannya. Jika didialogkan 
dengan Darminta ${ }^{10}$, pembinaan rohani merupakan usaha untuk menjadi hamba beriman, sebab pada dasarnya hidup merupakan penyerahan diri secara mutlak kepada Tuhan Yang Maha Esa.

Ibu tidak sendirian dalam memenuhi kebutuhan pendidikan anaknya, meskipun pendidikan saat ini bebas biaya Sumbangan Pembinaan Pendidikan (SPP). Namun masih ada biaya lain yang tidak terduga dan dirasa cukup besar bagi seorang ibu. Dalam Mengatasi hal tersebut, sekalipun ibu dan ayah telah bercerai masih ada kerjasama dalam memenuhi kebutuhan pendidikan anaknya. Ayah yang tidak menanggung biaya sehari-hari berusaha memenuhi kebutuhan pendidikan anaknya yang cukup besar seperti biaya daftar ulang, rekreasi, dan iuran sekolah yang jumlahnya

${ }^{10}$ Darminta. J., Praksis Pendidikan Nilai (Yogyakarta: Kanisius, 2004) 16. cukup besar. Dengan demikian biaya dalam pemenuhan kebutuhan pendidikan oleh ibu sebagai orang tua tunggal; memberi uang saku, membelikan perlengkapan sekolah, perlengkapan alat tulis, mengantar ke sekolah, memberikan fasilitas sepeda, memotivasi belajar dan menasihati dalam kegiatan ibadah sebagai bentuk pemenuhan pendidikan rohani.

Kebutuban Kesehatan

Kebutuhan kesehatan merupakan kebutuhan yang juga sangat penting bagi manusia, ketika manusia mengalami gangguan pada kesehatannya, maka segala aktivitasnya akan terganggu. Undang Undang Kesehatan Nomor 23 Tahun 1992, menyatakan sehat adalah suatu keadaan sejahtera dari badan, jiwa, dan sosial yang memungkinkan setiap orang hidup produktif secara sosial dan ekonomis. Upaya pemenuhan kebutuhan anak oleh 


\section{Isa Vila Rizki Ullabanati, Mahfudz Sidiq}

ibu dilakukan dengan cara memberikan pertolongan pertama ketika anak sedang sakit yaitu memberikan obat yang ada di warung atau apotek terdekat. Ketika anak tidak kunjung sembuh, maka ibu membawa anak tersebut ke puskesmas terdekat untuk pemeriksaan lebih lanjut. Hal tersebut sejalan dengan pernyataan Sumardi dan Evers ${ }^{11}$, bahwa pengeluaran untuk kesehatan adalah biaya yang dikeluarkan untuk berobat ke puskesmas ataupun rumah sakit, dukun ataupun pengobatan sendiri.

Kesehatan emosional untuk anak juga tidak kalah pentingnya dari kebutuhan lainnya. Perkembangan emosional anak merupakan hal yang sangat perlu diperhatikan oleh orang tua. Terlebih lagi ketika orang tua telah bercerai, pada masa tersebut, akan terjadi perubahan emosi yang meliputi perasaan malu, kesepian, marah, kesadaran diri, dan

\footnotetext{
${ }^{11}$ Sumardi. M dan Evers, HD, Kemiskinan dan Kebutuban Pokok (Jakarta: CV. Rajawali Press, 1982.), 326.
}

depresi. Beberapa anak yang menjadi korban perceraian menerima akibat yang dialami oleh perceraian kedua orang tuanya, selain itu, beberapa informan lainnya mengalami kesedihan dan tidak terima jika keduanya bercerai.

Menurut Maslow (dalam Dariyo $^{12}$ ), bahwa individu yang mengalami kematangan emosi memperlihatkan ciri-ciri yaitu: tidak ada sindrom atau gangguan psikoneurotik seperti rasa takut, khawatir, dan cemas. Mampu memandang kehidupan pribadinya secara positif yaitu memiliki insting atau pemahaman dan penerimaan yang baik. Mempunyai spontanitas, mampu bertingkah laku wajar, dan mudah menyesuaikan diri dengan keadaan, mampu menyelesaikan masalah yang dihadapi secara objektif dan tidak tergantung pada orang lain. Anak di Desa Tegalsari yang tinggal dengan ibunya memiliki kematan-

\footnotetext{
${ }^{12}$ Dariyo, A, Psikologi Perkembangan Dewasa Muda (Jakarta: Grasindo, 2004), 125.
} 
Vol. 12, No. 1, April 2019

p-ISSN:2086 -0749

e-ISSN:2654-4784

gan emosi. Ibu memberikan nasihat, sehingga anak mengerti akan kondisi orang tuanya saat ini. Bentuk pemenuhan kebutuhan kesehatan anak, baik fisik maupun emosional dilakukan dengan cara: memberikan pertolongan pertama pada anak ketika sakit, membawa ke dokter, memberikan lingkungan yang sehat, dan mengembalikan emosional anak.

\section{Kebutuban Berprestasi}

Orang tua sebagai tempat pendidikan pertama dan utama memiliki peran dalam proses sosialisasi. Kepribadian anak tergantung pada bagaimana pendidi-kan yang dibangun di dalamnya, sehingga apa yang dilakukan oleh orang tua terhadap anaknya akan berpengaruh pada anak tersebut. Begitu juga dalam me-menuhi kebutuhan prestasi anak, ia akan mengembangkan bakat dan minatnya dengan baik berkat arahan dan dukungan dari keduanya baik dalam akademik maupun non akademik.

Prestasi merupakan kebutuhan naluriah pada manusia untuk melakukan yang terbaik dari yang dia bisa. Menumbuhkan motivasi berperestasi pada anak bukanlah pekerjaan mudah, namun hal tersebut sangatlah dibutuhkan demi mencapai suatu tujuan yang lebih baik di masa mendatang. Pada penelitian ini prestasi anak diwujudkan dalam bentuk kegiatan sekolah untuk mengembang-kan minat dan bakat anak. Dalam mengembangkan minat dan bakat, anak mengikuti kegiatan ekstrakurikuler di sekolahnya, tidak hanya menekuni kegiatannya saja, melainkan juga mengasah kemampuannya dan dituangkan dalam beberapa lomba. Arahan dan dukungan yang diberikan oleh ibu sangat penting dalam mengembangkan prestasinya. 


\section{Isa Vila Rizki Ullabanati, Mahfudz Sidiq}

Slameto $^{13}$, menyatakan bahwa suatu minat dapat diekspresikan melalui suatu pernyataan yang menunjukkan suatu hal daripada hal lainnya, dapat pula dimanifestasikan melalui prestasi dalam suatu aktivitas. Anak yang memiliki minat terhadap suatu subjek tertentu cenderung untuk memberi perhatian lebih besar pada subjek tersebut. Anak korban perceraian mengikuti berbagai macam kegiatan karena setiap anak memiliki potensi yang berbeda-beda antara satu dengan lainnya. Sebagai orang tua, beberapa informan ibu memberikan dukungan dalam mewujudkan keinginan anak untuk mengembangkan minat dan bakatnya. Hal ini sejalan dengan Hurlock ${ }^{14}$, Realisasi diri memainkan peran penting dalam kesehatan jiwa, orang yang berhasil menyesuaikan diri secara

\footnotetext{
${ }^{13}$ Slameto \& Winkle, Belajar dan Faktor-Faktor yang Mempengarubinya (Jakarta: Bina Aksara, 1991 ), 180.

${ }^{14}$ Hurlock, E.B, Psikologi Perkembangan: Suatu Pendekatan Sepanjang Rentang Kehidupan. Alih Bahasa: Istiwidayanti \& Soedjarwo. Edisi Kelima (Jakarta: Erlangga,1999), 3.
}

pribadi dan sosial, maka akan mempunyai kesempatan untuk mengungkapkan minat dan keinginannya dengan cara yang memuaskan dirinya. Ibu memberikan dukungan dengan cara meluangkan waktunya untuk melihat kegiatan anak, memberikan arahan dalam mengembangkan minat dan bakat, memberikan perlengkapan yang menunjang kegiatan non akademik, dan dukungan moral pada anak.

$$
\begin{aligned}
& \text { d. Upaya Pemenuhan Kebu- } \\
& \text { tuhan Anak oleh Ayah } \\
& \text { Sebagai orang tua tunggal, }
\end{aligned}
$$
ayah memiliki pekerjaan yang lebih banyak. Selain dituntut mencari nafkah, ayah juga bertugas mengurus berbagai keperluan rumah tangga dan tugas yang sangat penting adalah memastikan perkembangan jasmani dan rohani anak serta memenuhi segala kebutuhan yang diperlukan. Menjadi orang tua tunggal dalam sebuah rumah tangga tidak mudah karena orang tua tunggal memiliki tanggung jawab yang lebih 
Vol. 12, No. 1, April 2019

p-ISSN:2086 -0749

e-ISSN:2654-4784

besar dibandingkan dengan mereka yang memiliki struktur keluarga normal atau lengkap. Temuan Dian $^{15}$ menunjukkan bahwa bagi seorang ayah yang harus mengasuh anaknya seorang diri karena bercerai dari istrinya. Tidak mudah bagi ayah dalam menjalankan perannya, selain itu kebutuhan anak juga harus terpenuhi agar dapat berkembang dengan baik. Upaya pemenuhan merupakan suatu usaha ayah sebagai orang tua tunggal dalam memenuhi kebutuhan anaknya. Berikut pemenuhan kebutuhan anak oleh ayah sebagai single parent.

\section{Kebutuban Pendidikan}

Setiap anak wajib dan berhak mengikuti pendidikan, menurut Undang Undang Nomor 20 Tahun 2003 tentang Sistem Pendidikan

\footnotetext{
${ }^{15}$ Dian, S, Peran Ayah sebagai Orang Tua Tunggal dalam Keluarga (Studi Kasus 7 Orang Ayah di Kelurahan Turikale Kabupaten Marus. Fakultas Ilmu Sosial dan Ilmu Politik Universitas Hasanudin Makassar, 2012), 3.
}

Nasional mengamanatkan bahwa setiap warga negara yang berusia $7-$ 15 tahun wajib mengikuti pendidikan dasar. Pendidikan dasar yang dimaksud dikhususkan pada pendidikan formal yaitu dari jenjang sekolah dasar sampai sekolah menengah pertama. Ayah sebagai orang tua tunggal berupaya keras untuk memenuhi kebutuhan pendidikan yang terbaik untuk anakanaknya.

Cara yang paling tanpak dari pemenuhan kebutuhan anak yang dilakukan oleh ayah yaitu dengan memberikan perlengkapan sekolah, perlengkapan alat tulis, dan membayar biaya sekolah. Selain itu, ayah juga memberikan uang saku untuk anak setiap harinya. Sejalan dengan pendapat Sumardi dan Evers ${ }^{16}$ yang termasuk biaya pendidikan anak sekolah meliputi uang atau biaya

\footnotetext{
${ }^{16}$ Sumardi. M dan Evers, HD, Kemiskinan dan 327.
} 


\section{Isa Vila Rizki Ullabanati, Mahfudz Sidiq}

BP3, SPP, alat sekolah, buku, transportasi, jajan, uang sekolah, sepatu, uang kaos kaki, uang tas sekolah, uang seragam pramuka, uang ujian, dan uang pendaftaran.

Ayah berperan memberikan arahan agar ia belajar namun tidak terlalu memaksakan anaknya agar terus belajar dan memantau bagaimana cara atau perkembangan belajar yang dilakukan oleh anak, karena anak sudah dianggap mampu belajar sendiri. Pada kenyataan di lapangan ayah sebagai orang tua tunggal memberikan kelonggaran kepada anaknya untuk mengatur dirinya sendiri. Meskipun diberi kelonggaran dalam belajarnya, anak tetap memiliki prestasi yang baik di sekolahnya, terbukti anak dari ayah single parent masuk dalam sekolah favorit di Ambulu. Berdasarkan pemaparan di atas dalam memenuhi kebutuhan pendidikan ayah memenuhi kebutuhan anaknya dengan cara memberikan perlengkapan sekolah, memberikan perengkapan alat tulis, mengantar sekaligus men- jemput anak sekolah, memberi uang saku, dan memberi perhatian pada anak.

\section{Kebutuban Kesebatan}

Anak sebagai individu yang unik, memiliki kebutuhan sesuai dengan tahap perkembangannya termasuk kebutuhan kesehatan. Kebutuhan kesehatan pada setiap anak juga berbeda-beda dan penanganannya juga berbeda. Ayah sebagai orang tua tunggal memiliki waktu yang sedikit bagi anaknya, sehingga ketika anak sakit orang yang pertama kali mengetahui adalah nenek/kakek yang tinggal bersama. Ketika anak sedang sakit yang di lakukan oleh orang tua adalah memberikan pertolongan pertama dengan memberikan obat di warung atau toko terdekat. Jika belum sembuh, maka orang tua membawa anak untuk pergi ke dokter. Hal tersebut seperti yang dinyatakan oleh Sumardi dan Evers ${ }^{17}$ bahwa pengeluaran untuk kesehatan adalah

\footnotetext{
${ }^{17}$ Sumardi. M dan Evers, HD, Kemiskinan dan .......... 326.
} 
Vol. 12, No. 1, April 2019

p-ISSN:2086 -0749

e-ISSN:2654-4784

biaya untuk berobat ke puskesmas ataupun rumah sakit, dukun ataupun pengobatan sendiri. Perawatan ketika anak sedang sakit dilakukan oleh nenek/kakek yang tinggal bersama karena ayah juga mencari uang untuk bekerja. Terkadang ibu dari anak yang sedang sakit datang untuk menjenguknya.

Berdasarkan penelitian yang dilakukan bahwa anak mengalami kesedihan dikarenakan takut akan kehilangan figur dan kasih sayang dari ibu. Menurut Gunarsa ${ }^{18}$ perceraian merupakan suatu penderitaan, pengalaman traumatis bagi anak. Anak memperoleh banyak tekanan dalam arti suasana rumah kurang harmonis dan ketiadaan ayah. Juga lingkungan yang mengharuskannya mengadakan perubahan dan penyesuaian diri. Untuk mengembalikan keadaan emo-

\footnotetext{
${ }^{18}$ Gunarsa. S. D, Dasar dan Teori Perkembangan Anak (Jakarta: Gunung Mulia, 2006), 166.
}

sional anak seperti dahulu fungsi afektif orang tua sangat diperlukan oleh anak seperti perlindungan dan dukungan psikososial dari keduanya. Fungsi afektif yang diberikan oleh ayah kepada anak akan memberikan kepercayaan diri. Seseorang yang memiliki rasa percaya diri akan lebih lebih produktif. Sebaliknya anak yang kurang memiliki rasa peraya diri akan cenderung merasa rendah diri, tidak berdaya, dan bahkan kehilangan inisiatif atau kebutuhan berpikir.

Mengembalikan rasa percaya diri merupakan suatu bentuk kebutuhan emosional, oleh karena itu ayah sebagai orang tua tunggal memiliki peran dominan. Ayah yang tinggal bersama dengan anak memenuhi kebutuhan kesehatan emosional dengan cara: memberikan pengakuan kepada anak, semangat dan motivasi kepada anak, memberikan perhatian dan 


\section{Isa Vila Rizki Ullabanati, Mahfudz Sidiq}

terlibat langsung dalam kegiatan akademik dan sosial anak, tidak berkata kasar ketika sedang menasihati, dan menghargai pilihan anak. Pemenuhan kesehatan emosional anak yang dilakukan oleh ayah sejalan dengan pernyataan Santrock ${ }^{19}$, mereka sulit untuk berkompetisi atau menerima kritik. Ada beberapa cara meningkatkan percaya diri yaitu: identifikasi domain kompetensi yang dianggap penting bagi anak, dukungan emosional dan persetujuan sosial, serta prestasi. Pemenuhan kebutuhan anak di berikan oleh orang tua cukup bervarisi dikarenakan setiap orang tua memiliki pola asuh berbeda-beda. Pada kondisi lapangan pemenuhan kesehatan emosional anak dengan cara memberikan penjelasan, membangun kedekatan, memberikan perhatian, dan nasihat. Kebutuban Berprestasi

Orang tua wajib hukumnya memenuhi kebutuhan dasar anak,

\footnotetext{
${ }^{19}$ Santrock. J. W, Perkembangan Anake (Jakarta : PT. Erlangga, 2007), 67.
}

tidak terkecuali kebutuhan berprestasi. Kebutuhan berprestasi pada anak korban perceraian terpenuhi dengan baik, namun yang menjadi sedikit masalah adalah sebagian orang tua (ayah) yang tinggal dengan anak kurang mengetahui bahwa anak mengikuti kegiatan di bidang non akademik. Padahal bentuk dukungan orang tua sangat berarti bagi perkembangan anaknya. Seperti yang diungkapkan oleh Mazuki $^{20}$ bahwa orang tua atau pendidik harus memberikan respon positif kepada anak, yang ditunjukkan dengan sikap, perhatian, serta mendengarkan secara aktif terhadap apa yang dikemukakan oleh anak. Apabila orang tua bersikap cuek terhadap anak, maka akan membangkitkan perasaan perih pada nuraninya.

Dukungan emosional dan persetujuan sosial juga merupakan hal yang dapat mempengaruhi pres-

\footnotetext{
${ }^{20}$ Marzuki. A. C, Anak Saleh dalam Asuban Ibu Muslimah (Yogyakarta: Mitra Pustaka, 2004), 131-132.
} 
tasi anak. Meskipun beberapa ayah kurang peka dalam memenuhi kebutuhan berprestasi anak, namun dalam memenuhi kebutuhan untuk menunjang kegiatan dibidang non akademik tetap terpenuhi dengan cara memberikan izin dalam kegiatan dan memberikan perlengkapan penunjang kegiatan yang dilakukan.

\section{Simpulan}

Berdasarkan hasil penelitian Pemenuhan Kebutuhan Anak oleh Orang Tua Pasca Perceraian, maka terdapat tiga kebutuhan yang harus dipenuhi sebagai berikut:

\section{Kebutuban}

Pendidikan;

Umumnya orang tua baik ayah ataupun ibu dalam memenuhi kebutuhan pendidikan anaknya memiliki polanya hampir sama yaitu memberikan perlengkapan sekolah, mengantar jemput anak, memberikan perlengkapan tulis, dan membayar iuran sekolah. Namun yang berbeda dalam memberikan motivasi belajar pada anak. Anak yang tinggal bersama ibu lebih serius dan disiplin, sedang yang bersama ayah lebih diberikan kebebasan dalam belajar. Demikian pula dalam memberikan pendidikan rohani ibu nampak lebih ajek, dan agak jarang diberikan oleh ayah yang tinggal bersama dengan anaknya

\section{Kebutuban Kesehatan; Ketika} anak sakit baik ayah atau ibu sebagai single parent memberikan pertologan pertama pada anak. Namun yang membedakan cara merawatnya. Ketika anak tinggal bersama ibu, maka ibu merawat anak keseharian di rumah. Berbeda, anak yang tinggal bersama ayah ketika sakit, yang menjaga dan merawatnya yaitu nenek/kakek karena alasan bekerja di pagi dan pulang di sore hari.

Kebutuban Berprestasi; Pemberian dukungan dalam mengem- 


\section{Isa Vila Rizki Ullabanati, Mahfudz Sidiq}

bangkan minat dan bakat pada anak memiliki perbedaan antara ayah dan ibu. Jika ibu lebih memberikan arahan dalam mengembangkan minat dan bakat, sedangkan ayah memberi kebebasan untuk memilih kegiatan yang disukai dalam mengembangkan minat dan bakat pada anak. Dengan demikian novelty dari penelitian ini adalah pemenuhan dasar anak, ibu lebih dominan memenuhi kebutuhan ke dalam sedangkan ayah lebih dominan ke luar.

\section{Daftar Pustaka}

Darminta. J. Praksis Pendidikan Nilai. Yogyakarta: Kanisius, 2006.

Dariyo, A. Psikologi Perkembangan Dewasa Muda. Jakarta: Grasindo, 2004.

Gunarsa. S. D. Dasar dan Teori Perkembangan Anak. Jakarta: Gunung Mulia, 2006.

Hurlock, E.B. Psikologi Perkembangan: Suatu Pendekatan Sepanjang Rentang Kebidupan. Alih Bahasa: Istiwidayanti \& Soedjarwo. Edisi Kelima. Jakarta: Erlangga, 1999.
Ihromi, T.O. Bunga Rampai Sosiologi Keluarga. Jakarta: Yayasan Obor Indonesia, 2004.

Marzuki. A. C. Anak Saleh dalam Asuban Ibu Muslimah. Yogyakarta: Mitra Pustaka, 2004.

Santrock. J. W. Perkembangan Anak. Jakarta : PT. Erlangga, 2007.

Sarwono. S.W. Psikologi Sosial Individu dan Teori-Teori Psikologi Sosial. Jakarta: Balai Pustaka, 2002.

Slameto \& Winkle, Belajar dan Faktor-Faktor yang Mempengarubinya. Jakarta: Bina Aksara, 1991.

Sugiyono, Memahami Penelitian Kualitatif. Bandung: Alfabeta, 2015.

Sumardi. M dan Evers, HD. Kemiskinan dan Kebutuban Pokok. Jakarta: CV. Rajawali Press, 1982.

https://www.bps.go.id/linkTableD inamis/view/id/893 (diakses pada 8 Oktober 2017)

http://regional.kompas.com/read/ 2016/03/20/19255241/Men sos.Jatim.Penyumbang.Terbe sar.Perceraian.di.Indonesia (diakses pada 8 Oktober 2017) 
An-Nisa' : Jurnal Kajian Perempuan \& Keislaman

Vol. 12, No. 1, April 2019

p-ISSN:2086 -0749

e-ISSN:2654-4784

http://m.suarajatimpost.com/read

/3472/20161215/122929/an gka-perceraian-di-kabupatenjember-masih-tinggi/ (diakses pada 9 Oktober 2017)

Dian, S. 2012. Peran Ayah sebagai Orang Tua Tunggal dalam Keluarga (Studi Kasus 7 Orang Ayah di Kelurahan Turikale Kabupaten Marus. Fakultas Ilmu Sosial dan Ilmu Politik Universitas Hasanudin Makassar)

Undang-Undang No. 23 Tahun 1992 Tentang Kesehatan

Undang-Undang No 20 Tahun 2003 Tentang Sistem Pendidikan Nasional 